\title{
Restriction Spectrum Imaging
}

National Cancer Institute

\section{Source}

National Cancer Institute. Restriction Spectrum Imaging. NCI Thesaurus. Code C143150.

A diffusion-weighted MRI technique that utilizes data obtained from multiple b-values and diffusion directions to measure diffusion orientation and leng th scale; it has been used to identify distinct microscopic tissues based on water diffusion behavior. 